\title{
DEVELOPING EDUCATION AS AN OPPORTUNITY FOR MEDIUM-DEVELOPED COUNTRIES IN THE CONTEXT OF INNOVATIVE REVOLUTION: A CASE OF UKRAINE
}

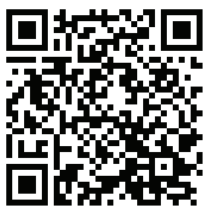

To cite this article:

\author{
Victor Ognevyuk, Dr. Sc., Prof. \\ Rector, Borys Grinchenko Kyiv University, \\ Kyiv, Ukraine \\ rector@kubg.edu.ua \\ https://orcid.org/000-0002-8671-3348
}

\begin{abstract}
The article defines the role of education as a resource for development for countries with transient economies based on the analysis of Ukraine's educational potential, and their involvement in international innovation process. It also deals with the advantages of education, compared to other segments of economy, which allows such countries to participate in the innovative revolution. In this research we analyzed international comparative data to reveal the weak and strong points of Ukrainian education and consequently to offer means of improving its effectiveness and competitiveness for revealing properly its potential.
\end{abstract}

Key words: education; competitiveness; financing, innovative revolution; investments, rating.

\section{INTRODUCTION. PROBLEM STATEMENT}

Education is an important category of economy and politics. Global information society and economic competition require every country, and person, for that matter, to demonstrate flexibility and aptitude to absorb and produce new knowledge. The controversial experience of Ukraine shows that overcoming discrepancies between education and production leads directly to convergence of economy and research, along with removal of technological underdevelopment, supply of top quality workforce, which match the advancing and rapidly upgrading production technology.

The transformations of contemporary world have been most dynamic compared to previous history of humankind, consequently those communities which fail to keep in pace with those transformations face their imminent oblivion. Contemporary economy is decreasing natural resources abuse detrimental to the environment, so development of education, research and innovation become instrumental.

Oil and gas as driving vehicles of some countries' economies, accompanied by coal and iron mining, or agriculture, just like Ukraine's case, when grain export constitutes the bulk of Ukrainian export, all of them fail to provide the formerly respected place among other economies, once the latter chose to take the path of innovation. In this research we analyzed 
international comparative data to reveal the weak and strong points of Ukrainian education and consequently to offer means of improving its effectiveness and competitiveness for revealing properly its potential. Thus, the issue under discussion is topical.

\section{LITERATURE REVIEW}

Researching the role of education in the value system of sustainable human development, especially in the context of extending the innovation revolution to transient economies, is diversified between philosophers, politicians, economists, sociologists and educationalists, demonstrating little correspondence and lack of complex approach.

Thus, J. Delors (Delors, 1999) offered four basic principles, four pillars of education in the $21^{\text {st }}$ century: 1 . Co-existence means to do things together or to solve inevitable conflicts peacefully and wisely; 2 . Learning means to combine pretty wide and general knowledge with the ability to penetrate the mysteries of a narrow scope of issues; 3 . Work means improving in one's qualification and acquiring competencies to cope with new unpredictable challenges; 4 . Life means requiring everyone show more independence, evaluation and enhanced personal accountability in group projects.

An attempt of philosophic evaluation of contemporary information age was done by the founder and Executive Chairman of the World Economic Forum Klaus Schwab, in his thought-provocative publication The Fourth Industrial Revolution. What it Means and How to Respond, first published in December, 12 ${ }^{\text {th }}, 2015$, in The Foreign Affairs (Foreign Affairs, 2015), further known at the World Economic Forum in Davos in January, 20 $23^{\text {rd }}, 2016$; in Davos-Klosters (Switzerland) in January, 17-20 ${ }^{\text {rd }}, 2017$; in Davos-Klosters (Switzerland) in January, 23-26 $6^{\text {rd }}, 2018$.

A solid basis for analysing dynamics of Ukrainian education standing in comparison to other countries constitute recent ten years' volumes of the Global Competitiveness Report (The Global Competitiveness Report, 2008; 2009; 2010; 2011; 2012; 2013; 2015, 2016, 2017). In tune with Charter 1.2 "Drivers of Long-Run Prosperity: Laying the Foundations for an Updated Global Competitiveness Index" the Global Competitiveness Report 2015-2016, modern interpretation of education can comprise a stock of skills and competencies, along with other qualities, that increase the workforce's productivity; it is an important component of any country's human capital assets, which through the increase of individual worker's effectiveness helps the economy progress from creating added value in manual work or simple physical operations to digital technology (The Global Competitiveness Report, 2015-2016). In tune with Charter 1.2 "Drivers of LongRun Prosperity: Laying the Foundations for an Updated Global Competitiveness Index" the Global Competitiveness Report 2017-2018, it is stressed that quality of higher education and training is crucial for economies that want to move up the value chain beyond simple production processes and products. In particular, today's globalizing economy requires countries to nurture pools of well-educated workers who are able to perform complex tasks and adapt rapidly to their changing environment and the evolving needs of the production system (The Global Competitiveness Report, 2017-2018).

Exploring human capital assets T. Schultz identified precedence of adults' professional training at workplace over students' formal education quality. As T. Schultz proves, education empirically transforms the whole country's economy (Schultz, 1961).

According to E. Hanushek and D. Kimko (Hanushek \& Kimko, 2000), when it comes to education the key factor is not the number of years for studies but the quality 
of education and the relevance of acquired content to the future economic immersion of a student. Whereas traditional reading, writing and arithmetic skills remain in the scope of education tasks the modern information technology age demands vital emphasis on dissemination of knowledge and innovation.

The traditional correspondence between competitiveness and capital, operating expenses and other resources become history in the contemporary dynamic world where information technology and communication afford generating and spreading knowledge with unprecedented speed. As C. Dahlman, Georgetown University professor says, competitiveness is mostly based on the ability to catch up with rapid technological and managerial achievements (Rising to the Challenge..., 2012).

Human Development Report 2018 (Human Development Report 2018. Work for Human Development, 2018) contains important data about systemic evaluation of mankind's vulnerability and offers ways of improving its resilience. The data in the Report verify that real progress of human development includes expanding opportunities and ability to get education for people alongside with access to medical care, life standards and personal safety. Analytical reports of the World Bank also afford useful information regarding the issues raised in this publication (The World Bank..., 2016).

Satisfying the social and industrial demand in rethinking the changes the world is going through involves new spheres, like politics, economy and management, in addition to the high-flown abstract philosophizing. So, the people who are directly involved in designing the present and projecting it into the future are compelled to express their opinion of contemporary and future state of affairs offering better protocols for decision-making and best practices. For instance, analyzing the impact of working-place computerization in 702 professional areas in the USA, come to the conclusion that about $47 \%$ of employed people appear in the risk zone, in particular, the majority of transport, logistics, office and administrative workers (Frey \& Osborn (n.d.)).

As K. Schwab states, the world stepped into the historic fourth stage of industrial revolution at the end of the $20^{\text {th }}$ century when cyber-physical systems became instrumental (Schwab, 2015). This fourth stage, in K. Schwab s terms, can be also interpreted through American sociologist and philosopher A. Toffler's theory of agrarian, industrial and information waves, emerging as the age of intellect and digital revolution characterized by unprecedented speed and complexity of changes, unlimited access to information and knowledge, technological fusion, which blur the margins of physical, digital and biological environments (Toffler, 2000).

The aim of research is to expose the main reasons for discrepancies in Ukraine's development from the inherited $20^{\text {th }}$ century economy and its perspectives if an innovative model for quality education, advanced research and information technology is adopted.

\section{MAIN RESULTS}

\section{New Trend in Economy and the Ukrainian reality}

On the one hand, Ukraine is a country with a medium economic development, yet listed highly in human development. In March 2017 the UN presented Human Development Report 2016. Work for Human Development, published for the United Nations Development Programme (UNDP) where experts rated 188 countries based on 2015-year's data calculated index. Human Development Index is an average indication of a person's development in a concrete country. It is a sum of three components for 
long-term progress evaluation in life expectancy, education and dignified life standard. Ukraine scored 0.743 finding itself on the $84^{\text {st }}$ position going ahead of China (being on the 90-ieth). From 1994 to 2014 the HDI of Ukraine increased from 0.705 to 0.747 , which constitutes $6.0 \%$ total or $0.24 \%$ per year. However, already in 2016 this indicator decreased by 3 positions in comparison to the previous report, when Ukraine occupied 81st position. However, Ukraine is lagging behind the leaders of the rating. According to the given data, the top country of the HDI list is Norway, scoring 0.949 . This country also heads the list of Inequality-adjusted Human Development Index list of top countries.

It is important to consider the special state Ukraine is presently in. In 2015 the Ukrainian economy shrank by $10 \%$ due to unprecedented shock of Russian invasion and Crimean occupation, the war in its East, also accompanied by the dropping prices for raw resources in the global market. It is natural, that under such unfavourable conditions limited local resources and external foreign investments are directed towards macroeconomic stabilization of the country providing financial and social support. Thus, in 2017 the World Bank's investment portfolio in Ukraine constituted \$ 2.8 billion (The World Bank..., 2016). Most of it is used for maintaining the basic state services in water supplies and communications, heating, electricity, transport, developing private sector, medical care, social security and health care. Consequently, the investments in education and research reforms are insufficient, so Ukraine has to rely upon its own potential. Thus, annual share of international grants in the overall Ukrainian research financing is shrinking, in 2013 constituting $21.6 \%$, in $2014-19.8 \%$, in $2015-18.2 \%$.

The policy of reducing budgeting misbalance, adopted by the Ukrainian government, yields noticeable results in the short- and mid-term perspective, yet the challenges of budgeting at all levels, including budgets for education, research and culture, remain huge. On the other hand, Ukraine is struggling to provide its people with better-quality education and to develop research and education as the key component of the country's innovation development. In his article in the Forbes in April, $14^{\text {th }}, 2016$, the Chairman of Ukrainian Economic Freedoms Foundation M. Zablotskyy says, that currently 343 programs of technical support with a total budget of $\$ 3,3 \mathrm{bln}$. are being implemented. It constitutes 5\% of Ukraine's GDP. Almost every second one is provided by the USA. Yet, the effectiveness of these programs is low (Zablotskyy, 2016).

The age of economic prosperity resting on exploiting the planet's natural resources and environmentally harmful industries is irrefutably vanishing thus revealing the instrumental value of education, research and innovation. Oil and gas, many exporting countries have been clinging onto, including coal-, ore-mining and agriculture, a substantial component of Ukraine's export too, have failed to maintain leadership in the competition between countries.

In Ukraine, however, agricultural export remains on the industrial stage level, in particular, in 2014 over $70 \%$ of it were metal, minerals, agricultural cultivated products and food. And in 2017, for example, in the structure of the export of Ukrainian goods in 2017 the biggest share was constituted by agrarian and food production (41,3\%), metallurgical complex production (23\%), machine building production $(11,4 \%)$ and mineral products $(9,5 \%)$ (Eksport rastet..., 2018). Instead, the outcome of machinebuilding industry, electronics, transport, and chemicals, the markers of $20^{\text {th }}$ century success, amounted to 15\% (Meleshchuk, 2016). Meanwhile, Ukraine is constantly increasing the distance from world trade tendencies, which threatens not only its ratings in the world market but also its national security. 
Evidently, the oil-and-gas age is over, modern and future technologies can fully cover the need in renewable energy for the humankind. It does not necessarily lead to a shift to "grain"-age in the hope of Ukrainian soil's fertility and becoming world's monopolist in grain export.

Production of black iron, coal mining, export of wood or agricultural goods to the world market, being the cornerstones of many Ukrainian politicians' economic thinking, are the way for Ukraine to get stuck between the second and third waves of development. Therefore, Ukraine will never make a quality leap in its future without investing in human capital and innovative development.

\section{Ukraine's ratings in the Index of Human Development and the Knowledge Economy Index}

When the whole world is focusing on education, knowledge and intellect, readjusting to innovative technologies, Ukraine is still resting on the old industrial and agricultural approaches. At the same time, educational and research potential of Ukraine is highly competitive. According to UNESCO (2010) researchers constitute 1001 - 2000 people per 1 million of the country's population, which is quite a high score.

Table 1

\section{Qualified workers involved in research and technological research in Ukraine (thousand people), author's}

\begin{tabular}{|c|c|c|}
\hline Year & Full-time workers & Part-time workers \\
\hline 1995 & 179.8 & 41.7 \\
\hline 2000 & 120.8 & 53.9 \\
\hline 2005 & 105.5 & 68.5 \\
\hline 2014 & 109.6 & 46.9 \\
\hline 2015 & 101.6 & 41.7 \\
\hline
\end{tabular}

Yet, Ukraine's share in the world's market high-tech driven segment is pitifully small, amounting to $0.1 \%$ only, with relative share of high-tech production constituting around $1 \%$ of Ukraine's GDP, innovative activity of industries is critically low and the facilities and resources of research institutions get rapidly outdated.

According to the World Bank's 2012 estimation Ukraine was rated 56 $6^{\text {th }}$ among 146 countries in the Knowledge Economy Index (KEI) 2012 Ranking, scoring 5.73. Leading countries score over 8.21. The top five of the rating are Sweden, Finland, Denmark, the Netherlands and Norway. According to KEI Ukraine is on the 21 position and tops the list of countries with weaker and mid-integrated economies due to its high scores in education and workforce qualification.

Obviously, the country needs a new development strategy, which will be based on extensive involvement of national intellect, providing the country's sustainable renewal and development, production of new technology, creative and intellectual production. The new national budget, however, adopted at the end of 2017 in Ukraine, does not 
add optimistic notes to the idea of holistic national strategy for education and research development being available to provide a solid basis for the country's innovative development and its successful competition in the modern world. Allowing 95.47 billion UAH for education and qualification, leaving out modernizing schools, leads to incoherent use of funds and people resources and is blatantly insufficient for an educational leap.

Table 2

Financing research and technological research in Ukraine, \%, author's

\begin{tabular}{|c|c|c|c|}
\hline Year & Total financing & National budget & External financing \\
\hline 2006 & 1.17 & 0.39 & 0.78 \\
\hline 2010 & 0.82 & 0.34 & 0.48 \\
\hline 2011 & 0.73 & 0.29 & 0.44 \\
\hline 2012 & 0.75 & 0.33 & 0.42 \\
\hline 2013 & 0.77 & 0.33 & 0.44 \\
\hline 2014 & 0.66 & 0.26 & 0.40 \\
\hline
\end{tabular}

The funds for research in the national 2018 budget constitute only 8.3 billion UAH (Kohut \& Stadnyi, 2015). It is also impossible to predict how much of it will be allotted to research proper, and what share will be used for its maintenance, although previous experience shows that research proper gets a small share.

It all amounts to the same fact - education and research are treated as expenses in the parliament and political circles. This approach demonstrates utter misconception of research's role and cannot be applicable to the state policy bringing more harm and depriving its intellectual potential. Productive and social outcome of people with profound education, especially in IT sphere, with high IQ, is incomparably exceeding those who are engaged in low-tech production. Correspondingly, people with quality education will win in life standards, life quality and lifespan.

Maintaining competitiveness and developing higher life standards for people requires an innovation-friendly environment. Consequently, it requires national and private investments in education, research and piloting, setting up and supporting innovative research facilities, which produce new knowledge, generating further advances in its turn, extensive cooperation in technological design and implementation between universities and industry, including intellectual property challenges.

Unlike the industrial age in the history of mankind, when countries competed for the natural resources and markets, the post-information wave competitiveness refocused on education, competence and highly creative innovators. Providing for education and research-based competition leads to the increase of workforce effectiveness, and consequently, to higher incomes and life standards.

\section{Position in the world and Ukraine's potential in education and research}

References to external evaluation help to confirm the high potential of Ukrainian education and to evaluate its present day conditions, tendencies and perspectives. Bloomberg's optimistic rating according to innovative index among 50 countries places Ukraine on the $46^{\text {st }}$ place with 47.28 index. The top ten of this rating is taken by South 
Korea scoring 89.28, Sweden 84.70, Singapore 83.05, Germany 82.53, Switzerland 82.34, Japan 81.91, Finland 81.46, Denmark 81.28, France 80.75 and Israel 80.64 - all being the countries with high investments in innovative projects and designs at the same time focusing on specialists in engineering. Unfortunately, in the top 50, our country turned out to be the worst in terms of economic productivity and hit the top three outsiders for the profitability of industry. At the same time, Ukraine retains a high $21^{\text {st }}$ position on the efficiency of higher education, which is based on the share of employees with higher education diplomas and the number of graduates with engineering and technical higher education. In patent activity, Ukraine also feels relatively confident - 27th out of 50 .

Cheap workforce, in other words, secures Ukraine's position in the top fifty by comparatively low salaries, rather than innovative technologies. Yet, a decisively high marker Ukraine scores the $5^{\text {th }}$ among other countries is the educational component. Due to its education, Ukraine is in the leaders' rating. Thus, showing that education can give the country a boost in competition.

Indeed, education is one of Ukraine's most 'quality' good, which can find its proof in the Global Competitiveness Report at the World Economic Forum in Geneva. According to the parameter "Quality of Primary Education" Finland is keeping its leadership position for several years running. It is accompanied by Belgium, Singapore, Switzerland and New Zealand. Ukraine's rating in this parameter was 42 (The Global Competitiveness Report, 2017-2018). Another positive move against previous evaluation is the parameter "Involvement in Primary Education" which demonstrated a leap in 32 points from the $94^{\text {th }}$ position to the $62^{\text {st }}$ position scoring 96.2\% of involvement. The top positions with the closest to a hundred per cent score are taken by Singapore, Canada, Japan and China, scoring 99.9\%.

The parameter "Involvement in Secondary Education" gives Ukraine the $51^{\text {st }}$ position scoring $99.2 \%$. If the parameter's requirement had been completion of secondary education Ukraine would have been the top of the list because the Constitution requires obligatory full secondary education from every citizen.

A significant achievement for Ukraine can be considered the change in the "Quality of Educational System" parameter, rising from the 72nd (The Global Competitiveness Report, 2014-2015) to the 56th position (The Global Competitiveness Report, 2017-2018).

According to the parameter "Quality of Education in Sciences" the world leaders are Singapore, Finland, Belgium and Switzerland. Ukraine's position does not rise above the thirtieth position. The parameter of school management quality throws us even to the $88^{\text {th }}$ position. To compare with other countries, like Latvia -51 , Japan -59 , Poland -71 , Georgia - 113 and Russia - 65 (The Global Competitiveness Report, 2017-2018).

Obviously, the case calls for urgent measures with decentralized school management, redistribution of authority and transition to professional upgrade based on leadership. Decentralization of the school management should allow central organs form effective policies in education, providing for standards and clearly defined expected results of education, which are disseminated to all institutions; and local authorities should be responsible for proper conditions for students and teachers, leaving it up to them to follow the curriculum, select corresponding methodologies and textbooks, thus allowing professional competence and freedom of educators.

Contemporary education strategy is inseparable from developing information and communication technologies. The parameter "Access to Internet" (The Global Competitiveness Report, 2017-2018) placed Ukraine on the $34^{\text {th }}$ position in The Global 
Competitiveness Report. Compared with the report for 2014-2015, Ukraine has risen by 34 positions: from the 67 th position to the 34 th.

Another massive evaluation by UNESCO Science Report (UNESCO Science Report: Towards 2030) focused on the idea that true science should lead the mankind to prosperity. The published results dwell on several key issues.

1. Contribution to science and the number of researchers and new findings are increasing more than the world economic growth. For example, in 2013 the world had 7.8 mln. of researchers, which is 20\% more than in 2007 (UNESCO, 2015). Most of scientists are concentrated in the European countries, the USA and China. The world leader in researchers per million people is Finland, scoring about 7.5 thousand, Denmark - 6.8 thousand, Singapore -6.8 thousand. Ukraine's score of 1.4 thousand landed the country in the same category with Latvia, Poland, Italy, Malta, Bulgaria, Argentina, Costa Rica and Serbia (UNESCO, 2015).

2. Priority of science, technology and innovation is the most effective stimulus for GDP and life standards growth. In this context of implementing effective innovations for economy growth, Ukraine is lagging behind its own high "happy 1980-ies indices, yet still correlating (remaining between $0.7-0.8 \%$ of GDP) with other middle-income countries focusing on less ambitious aims" (UNESCO, 2015).

3. Different countries' success in implementing research and innovation policies depends on the synchronicity, which their Cabinets achieve while developing fundamental research, technology, implementation and private investments in research.

The referred Report quite clearly shows Ukraine's strong points (in the chapter "Black Sea Countries" along with Armenia, Azerbaidzhan, Belarus, Moldova and Turkey) from the point of view of their research and education system development (UNESCO, 2015), along with weaker points hindering active involvement of the country into the innovation revolution. According to the Report, the drawback of Ukrainian model for research support is the dominance of state financing in science and lacking private capital investment; insignificant share of foreign capital in financing research; almost half of the state financial support is devoured by academies of science, including the National Academy of Science. The state is trying to involve private sector into scientific research although with limited success mainly, because of the common failure to deliver on its own promises when it comes down to financing projects. The Report says that the Government's policy in Ukraine in prioritizing human resources is "indifferent" and, in spite of numerous kinds of personal scholarships for researchers, does not focus on supporting researchers' exchange of experience in foreign countries (UNESCO, 2015).

\section{4. "Homework" for Ukrainian politicians in Education and Research}

With K. Schwab's idea as a starting point, estimating intellect over capital in producing goods and services, Ukrainian elites need to design a strategy for deep social transformations on the basis of new concepts. In spite of the fact that innovation issue and its implementation in each country is spiced with cultural peculiarities, there are still clear universal principles of strengthening competitiveness for those countries where education and research development are national priorities. For Ukraine we may start the list with the following ones:

- Priority investments in education reforms to provide intellectual and technical basis for the knowledge and competencies agents due to which innovative economy can function; 
- Substantial, i.e., not lower than 3\% of GDP, increase of national and private investments in research and its implementation;

- Formation of calculated estimation, alongside with mid- and further perspective of national innovation strategy, which clearly defines national priorities in economy, research and technology, including corresponding specialists' training, economic and political mechanisms for commercialization of research, entrepreneurship and access to capital.

- Acknowledging and legalization of opportunities for universities' co-funding both from national budget and business, which enables implementation of state-andbusiness partnership preserving the functioning of research and education institutions and providing their freedom in cooperation with business and commercialization of inventions, which can and should work as catalysts for economic growth.

- Focusing the national and business interests on programs encouraging the universities and research institutions to implement fundamental and applied research results in new products and processes.

- Political will of elite, leaders and the parliament to create institutional basis for protecting intellectual property, liberalization of taxation for promoting competitiveness of Ukrainian education and research, simplification of legal and bureaucratic procedures in licensing, patenting, certification, etc.

Traditionally, a university in Ukraine is regarded as a sporadic component in the national research framework, which, supposedly, concentrates only on training students. Until now most of Ukrainian universities treat foreign students' training as a mere means of external funding for their budgets. Yet, the potential of internationalization in education and research will not only fill the budget (according to the Ministry of Education and Science data, Ukraine gets an annual income of approximately $\$ 500 \mathrm{mln} / 13,5 \mathrm{bln} \mathrm{UAH}$ from foreign students) but also allow our current and future generations form a realistic worldview and contribute to the "diplomacy of knowledge".

Based on selected European values in its difficult times of political and economic crisis Ukraine has to combine digital and spiritual-intellectual revolution, focusing its progress on the personal value, on human life implemented in harmony with nature, society and universe. By making education and research the cornerstone of its national policy Ukraine has a chance and a momentum to develop in pace with the vanguard societies in the context of innovation revolution.

\section{CONCLUSIONS}

The progress of education, research and innovation becomes instrumental in the age when economic growth no longer depends on exploiting the natural resources of the earth and damaging its environment.

Coal, ores, iron and agriculture, being the case with Ukraine, cannot secure a worthy position among the countries, which preferred innovative development.

Ukraine has favourable pre-conditions for economic growth due to its high potential in the global education system, which should be regarded as an important indicator for innovation, trade, workforce and human capital development. In the world economy based on knowledge Ukraine is capable of implementing high-quality specialists' training who will upgrade current political, business and intellectual elite circles.

In the context of global society of knowledge, training specialists who are capable of performing within information society requires restructuring and improving 
professional competencies and mobility of both teachers and students in the whole system of Ukrainian education. With due support from the state and encouraging investments Ukrainian education will become a groundbreaking resource in the innovation development of Ukraine.

\section{REFERENCES}

Delors, J. (1999). Learning: treasure within. Report to UNESCO of the International Commission on Education for the Twenty -first Century. UNESCO Publishing. Retrieved from http://unesdoc.unesco.org/images/0010/001095/109590eo.pdf.

Eksport rastet: na infografike pokazali, chem i s kem torguet Ukraina [Exports are growing: they showed on infographics what Ukraine is trading with and with whom]. (2017, November 30). Segodnya. Retrieved from https://www.segodnya.ua/economics/enews/ eksport-rastet-na-infografike-pokazali-chem-i-s-kem-torguet-ukraina-1094912.html (accessed 10 October, 2018).

Frey, C. \& Osborn, M. (n.d.). The future of employment: how susceptible are jobs to computerisation? Retrieved from http://www.oxfordmartin.ox.ac.uk/downloads/academic/ The_Future_of_Employment.pdf.

Hanushek, E. \& Kimko, D. (2000). Schooling, Labour-Force Quality, and the Growth of Nations. The American Economic Review, 90 (5), 1184-208.

http://www3.weforum.org/docs/WEF_GlobalCompetitivenessReport_2013-14.pdf (accessed 10 October, 2018).

Human Development Report Work for Human Development. Published for the United Nations Development Programme (UNDP) (2015). Retrieved from http://www.nas.gov.ua/text/ pdfNews/2015_Human_Development_Report.pdf

Kohut, I. \& Stadnyi, Ye. (2015). Biudzhet osvity ta nauky 2016: shcho pryinialy deputaty [The budget of education and science 2016: what deputies have approved]. Retrieved from http://www.cedos.org.ua/uk/osvita/biudzhet-osvity-ta-nauky-2016-shcho-pryinialydeputaty (accessed 10 October, 2018).

Meleshchuk, S. (2016). Evoliutsiia ekonomichnoi skladnosti Ukrainy: bih na mistsi [Evolution of the economic complexity of Ukraine: running in place]. Retrieved from http://www. epravda.com.ua/publications/2016/01/19/577309/ (accessed 10 October, 2018).

Pidbereznyi, K. (2018). Ukraina za rik vtratyla chotyry pozytsii v hlobalnomu innovatsiinomu reitynhu Bloomberg [Ukraine lost four positions in the global innovation rating for the year Bloomberg]. Retrieved from https://kfund-media.com/ukrayina-za-rik-vtratylachotyry-pozytsiyi-v-globalnomu-innovatsijnomu-rejtyngu-bloomberg (accessed 10 October, 2018).

Rising to the Challenge: U.S. Innovation Policy for the Global Economy. National Research Council (US) Committee on Comparative National Innovation Policies: Best Practice for the 21st Century (2012). C .W. Wessner, A. W. Wolff (eds). Washington (DC): National Academies Press (US).

Schultz, T. (1961). Investment in Human Capital. The American Economic Review, 51 (1), $1-17$.

Schwab, K. (2015). The Fourth Industrial Revolution: what it means, how to respond, Retrieved from https://www.foreignaffairs.com/articles/2015-12-12/fourth-industrial-revolution (accessed 10 October, 2018).

The Global Competitiveness Report 2008-2009 (2008). World Economic Forum Geneva, Swit- 
zerland 2008. Klaus Schwab, World Economic Forum; Michael E. Porter, Harvard University, Retrieved from http://www3.weforum.org/docs/WEF_GlobalCompetitivenessReport_2008-09.pdf (accessed 10 October, 2018).

The Global Competitiveness Report 2009-2010 (2009). World Economic Forum Geneva, Switzerland 2009. Klaus Schwab, World Economic Forum; Xavier Sala-i-Martin, Columbia University. Retrieved from http://www3.weforum.org/docs/WEF_GlobalCompetitivenessReport_2009-10.pdf (accessed 10 October, 2018).

The Global Competitiveness Report 2010-2011 (2010). World Economic Forum Geneva, Switzerland 2010. Klaus Schwab, World Economic Forum; Xavier Sala-i-Martin, Columbia University, Retrieved from http://www3.weforum.org/docs/WEF_GlobalCompetitivenessReport_2010-11.pdf (accessed 10 October, 2018).

The Global Competitiveness Report 2011-2012 (2011). World Economic Forum Geneva, Switzerland 2011. Klaus Schwab, World Economic Forum; Xavier Sala-i-Martin, Columbia University, Retrieved from http://www3.weforum.org/docs/WEF_GCR_Report_2011-12.pdf (accessed 10 October, 2018).

The Global Competitiveness Report 2012-2013 (2012). World Economic Forum Geneva, Switzerland 2012. Klaus Schwab, World Economic Forum; Xavier Sala-i-Martin, Columbia University. Retrieved from http://www3.weforum.org/docs/WEF_GlobalCompetitivenessReport_2012-13.pdf (accessed 10 October, 2018).

The Global Competitiveness Report 2013-2014 (2013). World Economic Forum Geneva, Switzerland 2013. Klaus Schwab, World Economic Forum; Xavier Sala-i-Martin, Columbia University. Retrieved from

The Global Competitiveness Report 2014-2015 (2014). World Economic Forum Geneva, Switzerland 2014. Klaus Schwab, World Economic Forum; Xavier Sala-i-Martin, Columbia University. Retrieved from http://www3.weforum.org/docs/WEF_GlobalCompetitivenessReport_2014-15.pdf (accessed 10 October, 2018).

The Global Competitiveness Report 2015-2016 (2015). Full Data Edition. World Economic Forum. Retrieved from http://www3.weforum.org/docs/gcr/2015-2016/Global_Competitiveness_Report_2015-2016.pdf (accessed 10 October, 2018).

The Global Competitiveness Report 2017-2018 (2017). World Economic Forum. Retrieved from http://www3.weforum.org/docs/GCR2017-2018/05FullReport/TheGlobalCompet itivenessReport2017\%E2\%80\%932018.pdf (accessed 10 October, 2018).

The World Bank. IBRD-IDA. Ukraine Economic Update (2016, April 1), Retrieved from http://pubdocs.worldbank.org/pubdocs/publicdoc/2016/4/88201459504749749/ Ukraine-Macroeconomic-Update-April-2016-ENG.pdf (accessed 10 October, 2018).

Tofler, E. (2000). Tretia Khvylia [The Third Wave]. Kyiv: "Vsesvit". (in Ukrainian)

UNESCO (2015). UNECO Science Report: towards 2030 - Executive Summary. UNESCO Publishing, France. Retrieved from http://unesdoc.unesco.org/images/0023/002354/235407e. pdf (accessed 4 October, 2018)

Zablotskyy, M. (2016). Why Is Reform So Slow In Ukraine? Retrieved from http://www.forbes. com/sites/realspin/2016/04/14/reform-ukraine-aid/\#12b5d650307 (accessed 10 October, 2018). 